Arab World English Journal (AWEJ) Volume 12. Number3 September 2021

DOI: https://dx.doi.org/10.24093/awej/vol12no3.34

Pp.507-523

\title{
Boosted with Online Learning to Improve English Language Teachers' Proficiency
}

\author{
Szarmilaa Dewie \\ Faculty of Education, Universiti Kebangsaan Malaysia \\ Helmi Norman \\ Faculty of Education, Universiti Kebangsaan Malaysia, \\ Corresponding Author: helmi.norman@ukm.edu.my \\ Melor Md. Yunus \\ Faculty of Education, Universiti Kebangsaan Malaysia
}

Received: $7 / 8 / 2021$

Accepted: 8/24/2021

Published: 9/29/2021

\begin{abstract}
Language teaching and learning have been significantly transformed by the advent of online technology. Learning and information-gathering have been dramatically boosted by technology. Owing to online learning, physical geography is no longer a major obstacle. However, there has not been much study to portray online technologies and online learning improving teachers' proficiency in the English language. With this in mind, the purpose of this study was to investigate the extent to which online learning has improved teachers' language proficiency. About 201 teachers from eight districts in Malaysia were enrolled in an online course. The study was conducted online for three months. Data was collected from an evaluation survey obtained at the end of the period. Responses gathered based on descriptive analysis of the course content, overall experience, and comments derived from the survey was then analyzed from the data. The findings revealed that the teachers are very positive towards the course and found it constructive in enhancing their professional development. The results also indicated that teachers have also improved their language component upon being enrolled in the course. These documents that all the language skills have been enhanced, and they are very motivated. Therefore, future research should focus on a specific language component in order to gain a deeper insight of continuum from this study.

Keywords: English Language, online learning, learning management system, teachers' proficiency
\end{abstract}

Cite as: Dewie, A., Norman, H. , \&Yunus, M.M. (2021). Boosted with Online Learning to Improve English Language Teachers' Proficiency . Arab World English Journal, 12 (3) 507-523. DOI: https://dx.doi.org/10.24093/awej/vol12no3.34 


\section{Introduction}

Digitalization has been making its way into education for quite a while now. Though the number of different digital tools and platforms has varied quite a bit during the last few years, the trend is going upwards (Kaarakainen et al., 2017; Forsberg, 2018). Concerning this, Malmberg (2018) also highlighted that course content, learning goals, and behaviours must be incorporated to accomplish these procedures. They all work together to create the different methods in different ways. Instructional content, for example, an assignment, and the learner's attitude, will affect the learning outcome which is a mediating process. Hence, the aim of this research is to provide a language learning and professional development feature that is available online, enabling teachers in Malaysia to enhance their proficiency. It will be in tandem with the growth of online learning in teacher training and teacher education. As the current trend of teaching and learning through online learning leads to a better learning environment, producing or developing any online teaching materials would also be more effective if the course developer considers the intermediate processes involved before finalizing the products used, as stated by Rahmat et al. (2012). This resonates with Norman, Din, \& Nordin (2011), where the authors have mentioned that learning occurs in the flow and interaction between both learner and its environment, whereby cognitive authenticity of learning is more important than its physical authenticity. Henceforth, there is a need to create an avenue for learning to take place effectively. Thus, the study scrutinizes the potential of online learning in enhancing teachers' proficiency levels. The study set out to answer the following research questions.

1) How online learning helps teachers to improve teachers' language skills?

2) What is the usability of the online course?

3) To what extent is online learning effective in enhancing the English Language teachers' language proficiency.

4)

The research objectives are as below.

1) to identify how online learning help teachers to improve teachers' language skills

2) to investigate the usability of the online course

3) to explore the effectiveness of online learning in enhancing the English Language teachers' language proficiency.

The current Malaysian benchmark for teacher quality is based on the Ministry of Education's requirements, as cited by Kepol (2017). Students became the focus which led to the quality of teachers, and their proficiency became an alarming issue. This was clearly stated in the Malaysia Teacher Standards of 2009, which identified the urgent need for quality teachers with professional competence and proficiency as was emphasized by the Teacher Education Division. Hence, the rationale of this study is to produce teachers of quality where the training of teachers is emphasized. It is envisaged that the outcomes of this study would assist the Ministry of Education in establishing the teaching profession more favorable by encouraging educators to more excellent accountability standards. By doing so, the Ministry of Education will align its objectives with the aims and vision of the Malaysian Education Blueprint (MEB). Undoubtedly, the implication of this online learning is far-reaching, especially to the English language teachers in Malaysia. 


\section{Literature Review Online Learning}

According to Boettcher and Conrad (2016), online learning has gained interest among learners in recent decades. Undoubtedly, technologies have also improved in the last two years, which has increased their usage in both education and access training (Yunus, Umiera \& Hashim, 2019). The Internet and websites have also become the choice for formal and informal learners to access learning materials (Mc Greal, 2018). Since broadband Internet became available, online learning has become a practical alternative. Higher education is particularly rife with it, especially throughout the world (Krishnan \& Yunus, 2019). Meanwhile, Lee and Lee (2008) identified that online learning is an active process of information where knowledge is gained through understanding, development, and cooperation. Currently, the growth of the digital world has provided the globe with more convenient and substantial opportunities, as stated by Chua, Yunus, and Suliman (2019). Hence, this study recommends such a process so that teachers are empowered to be actively engaged.

Pramela and Hussin (2015) believed that in-service teachers are being aided to move toward innovative teaching and learning practices by utilizing online learning platforms. As classes are unrestricted and can be limitless, online learning is much preferred by learners and teachers. According to Ferri, Grifoni, and Guzzo (2020), workshops or training for teachers and students are required to increase their technological and pedagogical skills in online learning. Nguyen (2015) observed that virtual learners fared better in gaining knowledge than learners in face-to-face sessions. As Shea-Schultz and Fogarty (2002) describe it, the online learning approach accommodates a learning process that is flexible. A close connection between teachers and students means learning, doing, and knowing are all seamlessly intertwined. They highlighted that online learning makes learning so intuitive, subtle, powerful, varied, and most importantly, meaningful because learners get to learn at their own pace. Being borderless is another vantage point of online learning. Classroom learning imposes no time constraints. Continuous learning is fostered by Shea-Schultz and Fogarty (2002), and this is made possible by the programme.

Furthermore, the way we work has been changed by an electronic day (Major, 2015). Teaching and learning need not take place simultaneously at a specific time and place. Instead, learners get to learn at their own pace and complete tasks at a time most suitable for them and according to their ability. Despite the many roles, ICT is widely used as an educational tool (Hashim, Rafiq \& Yunus, 2019). Most importantly, the learning objectives and outcomes are set according to the learners' abilities, making online learning a suitable learning platform for learners of multiple intelligences. Thus, digital learning is the latest intervention in the teaching and learning (Yunus et al, 2019).

\section{Online Learning through Learning Management System}

With the advent of time, most educational organizations need strategies and platforms to ensure undergrads and educators can portray their exceptional aptitudes (Nordin et al., 2016; Adnan \& Ritzhaupt, 2018; Andersen et al., 2018; Hashim et al., 2018. Senteni (2006) has posited that when an LMS is used, the educational stakeholders must be immediately associated with the technical and social factors. Constructivists concede the importance of creating time for gaining knowledge because human beings develop new thoughts based on their current and previous 
information (Cavus, Uzunboylu \& Ibrahim, 2007). LMS provides the platform a constructive studying environment as it enables the management, delivery, tracking of the learning, testing, and communication process. It also monitors the registration and scheduling of the learners in their learning process. They further elaborated that this system allows educators and learners to have a free will to study with the dictum anywhere, anytime, and anyhow. The outcome of such a system is that teachers have flexible teaching and learning opportunities as well as get connected with their teaching fraternity amidst their busy schedules. When online learning via LMS is used, it is also simpler to monitor teachers' dedication and activity. This is because LMS provides a state-of-the-art set of equipment for monitoring both experienced and inexperienced persons' engagement in route activities. The LMS provides instant access to information regarding teachers' access, grades, and discussion board involvement, which depicts their vivid learning patterns.

\section{Teachers' Proficiency}

Proficiency among educators is the cornerstone of English language teaching. Therefore, it is one of the most significant and debated issues in language teaching and testing (Cardenas \& Chaves, 2013). Proficiency tests that test all the skills (listening, speaking, reading, and writing) are linked to standards such as the Common European Framework of Reference (CEFR) (Harley, Allen, Cummins, \& Swain, 1990).

Freeman et al. define a teacher's "command of English" as an increased level of English, meaning that teachers' capacity for the language is high. This is because teachers use the language for classroom teaching, and only when their proficiency is generally higher can classroom teaching be effective for student learning. Meanwhile, Freeman, Katz, Gomez, and Burns (2015) also indicate that teachers' proficiency is a specialized subset of language skills because they need to prepare lessons and teach them to the learners. Therefore, teachers' language proficiency is driven for specific content uses for contextual and classroom interaction (Freeman et al., 2015). Furthermore, teachers' language proficiency incorporates teachers' subject knowledge, second language acquisition theories, pedagogical knowledge, curricular, syllabus and, cultural knowledge (Richards, Conway, Roskvist, \& Harvey, 2013).

It is imperative that English language teachers have the appropriate level of competence in order to teach well and serve as role models to their students. As a result, the Malaysian Education Blueprint (MEB) and Roadmap 2015-2025 mandate that every English language teacher in Malaysia must have a minimum CEFR Level $\mathrm{C} 1$. This is done particularly to assure that students are not underserved in their language learning. Therefore, how best can teachers who have not reached this minimum CEFR level of $\mathrm{C} 1$ be upskilled? According to Yunus (2018), the technology currently has an impact on the development of pedagogy. Teachers who use technology in pedagogical instructions in classroom teaching can also learn via online learning. For this reason, all English language teachers can initiate their learning at their own pace and place using technology.

Past studies have disclosed that learners' use of effective and appropriate online learning strategies have led to a positive outcome (Artino, \& Jones, 2012; Fuller, Chalmers, \& Kirkpatrick, 1994; Hattie, Biggs, \& Purdie, 1996; Pintrich \& Johnson, 1990; Shih, 2005; Zimmerman, 1998). Moreover, Solak and Cakir (2015) posited that effective online learning 
strategies are essential as learning is fun-filled, accelerated, and learned more efficiently and effectively. To give a comprehensive review of relevant current research, Singh and Yunus performed a survey in 2021 in order to determine ESL teachers' opinions regarding the use of online learning and to identify challenges faced by them while using online learning. Their review combined data from 22 academic papers published between 2016 and 2020 from Google Scholar and Eric. Overall, the findings indicated positive reinforcement with the correct use and inclusion of online learning in the teaching of the English language, as this will help teachers perform better and produce a higher level of student quality in parallel to the requirement of the Malaysian Teacher Standards. Online learning, according to Maican and Cocorada (2021), makes language instruction and learning more adaptable and personalized, based on real resources, and may lead to an increase in attendance.

\section{Methods}

\section{Research Design}

The research design of this study is quantitative. A quantitative survey study was carried out by disseminating questionnaire to 201 respondents. The items in the questionnaire served the purpose on exploring teachers' perception on the usability of the online course to improve their language skills. The concern of this study was to investigate the effectiveness of the online learning course to enhance their proficiency. The researcher believes that online learning boosts the teachers to upskill their proficiency in line with the requirement of the national blueprint.

\section{Research Instruments}

The questionnaire consisted of two parts. Part A is the demographic details of the course participants and, Part B is the questions on the effectiveness of the online course. In general, responses on the suitability, areas of improvement, and efficacy of the online learning course were measured.

\section{Research Samples}

This study was conducted on 201 participants of purposive sampling from eight nationwide districts who were enrolled in a proficiency course. It was an online course fulfilling the requirement stipulated in the Malaysian Education Blueprint (MEB) initiative (Ministry of Education, 2013). The condition was for teachers who did not have CEFR C1 qualifications to be upskilled to a CEFR C1 level. The breakdown of the origins of the participants is shown in Table one below. There were 159 teachers from primary schools and 42 teachers from secondary schools enrolled in the online course.

Table 1. Enrolment of teachers

\begin{tabular}{|l|l|c|c|}
\hline \multicolumn{1}{c|}{ State } & \multicolumn{2}{c|}{ District } & Days \\
\hline Johor & Pasir Gudang & 25 & 90 \\
\hline Kelantan & Kota Bahru & 25 & 90 \\
\hline Perak & Kinta Utara & 25 & 90 \\
\hline Perlis & Kangar & 25 & 90 \\
\hline Pahang & Bentong & 25 & 90 \\
\hline Perak & Hulu Perak & 25 & 90 \\
\hline Pulau Pinang & Barat Daya & 25 & 90 \\
\hline
\end{tabular}


Arab World English Journal (AWEJ) Volume 12. Number 3. September 2021

Boosted with Online Learning to Improve English Language

Dewie,Norman \& Yunus

\section{Sabah}

Tawau 26

90

Total

201

\section{Data Analysis Procedures}

The questionnaire was developed to obtain constructive feedback from the teachers. It was formed by five English language lecturers from English Language Teaching Centre, Malaysia (ELTC). It was then reviewed and validated by another panel of experts from ELTC in finalizing the rubric, language, content, and appropriacy parallel to the course requirement.

\section{Data Collection Method}

The questionnaire comprised of two parts, the first part highlighted the demographics information, the second part is to discover respondents' perception of the online course. The respondents were required to complete the survey after completing the online learning course in the LMS. The survey questionnaires were disseminated to the course participants, who were the 201 teachers, upon the completion of the course enrolment The results were generated automatically by the system and then analyzed by the researcher, as shown below.

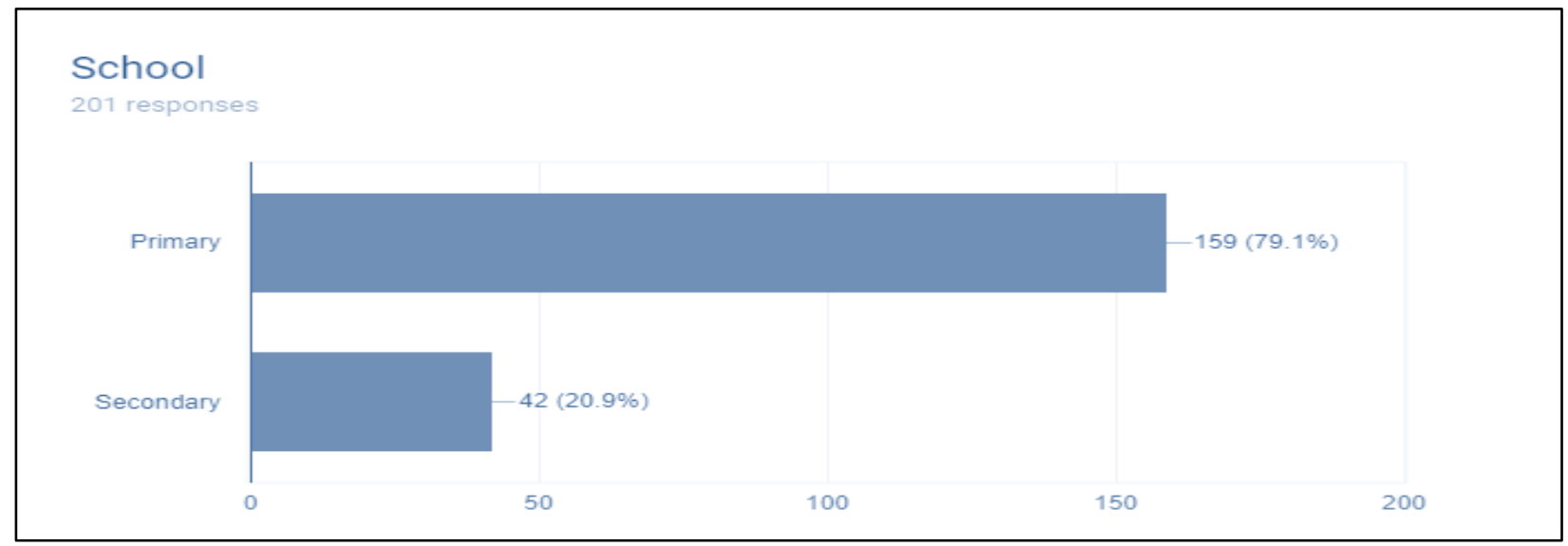

Figure 1. Primary and secondary school teachers

The course was a three-month foundation course for in-service teachers to enhance their proficiency in the English Language for personal development purposes. Online learning was developed to cater to the needs of current educators to provide them with the knowledge and practice in enhancing their proficiency level as well as aid them to sit for a proficiency exam to obtain minimum $\mathrm{C} 1$ in adhering to the requirement of $\mathrm{MEB}$. The course contents are in line with the Malaysian Roadmap policy and are open to the teachers via the Canvas Instructure Platform (LMS).

The learning tasks and instructions were specially designed for teachers according to the syllabus based on educational technology course, and this course was purely conducted via the Canvas Instructure platform. This platform enables learner autonomy through its threaded discussions, activities for assignments, and quizzes. This learner-centered model of instruction motivates teachers to become self-paced learners.

The degree of learning progress via LMS and online learning was investigated by evaluating the evaluation forms completed by participants at the end of the course. Apart from 
Arab World English Journal (AWEJ) Volume 12. Number 3. September 2021

that, firsthand observation of the participants' learning processes served as a noteworthy finding for the study. Of course, the course content played a vital role in assessing online learning as a viable tool to upskill learners' proficiency (teachers).

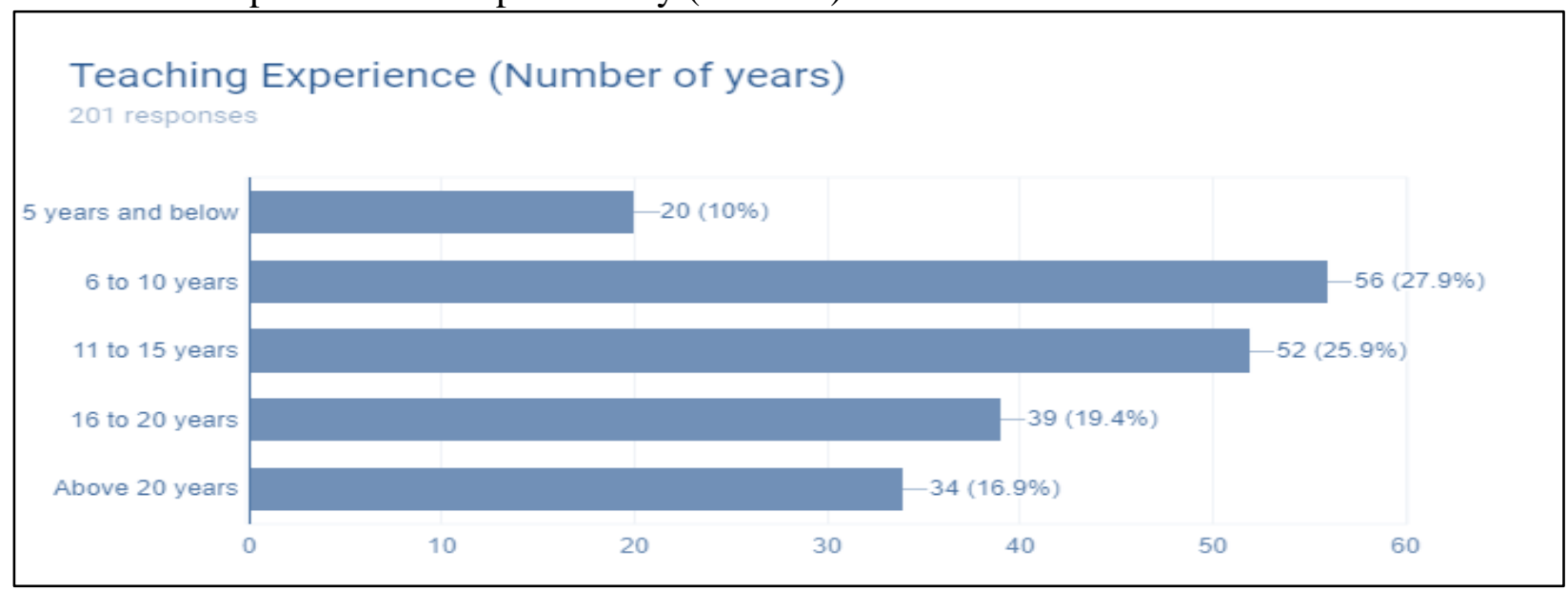

Figure 2. Number of years in teaching

The participants in this course came from a vast range of years of teaching experience. As the bar chart presents, 56 teachers had five to six years of experience, while 52 teachers had 11 to 15 years of experience. Thirty-nine of them had 16 to 20 years of teaching experience, while 20 had only five years or less. This data was accurate at the time when they enrolled for the course.

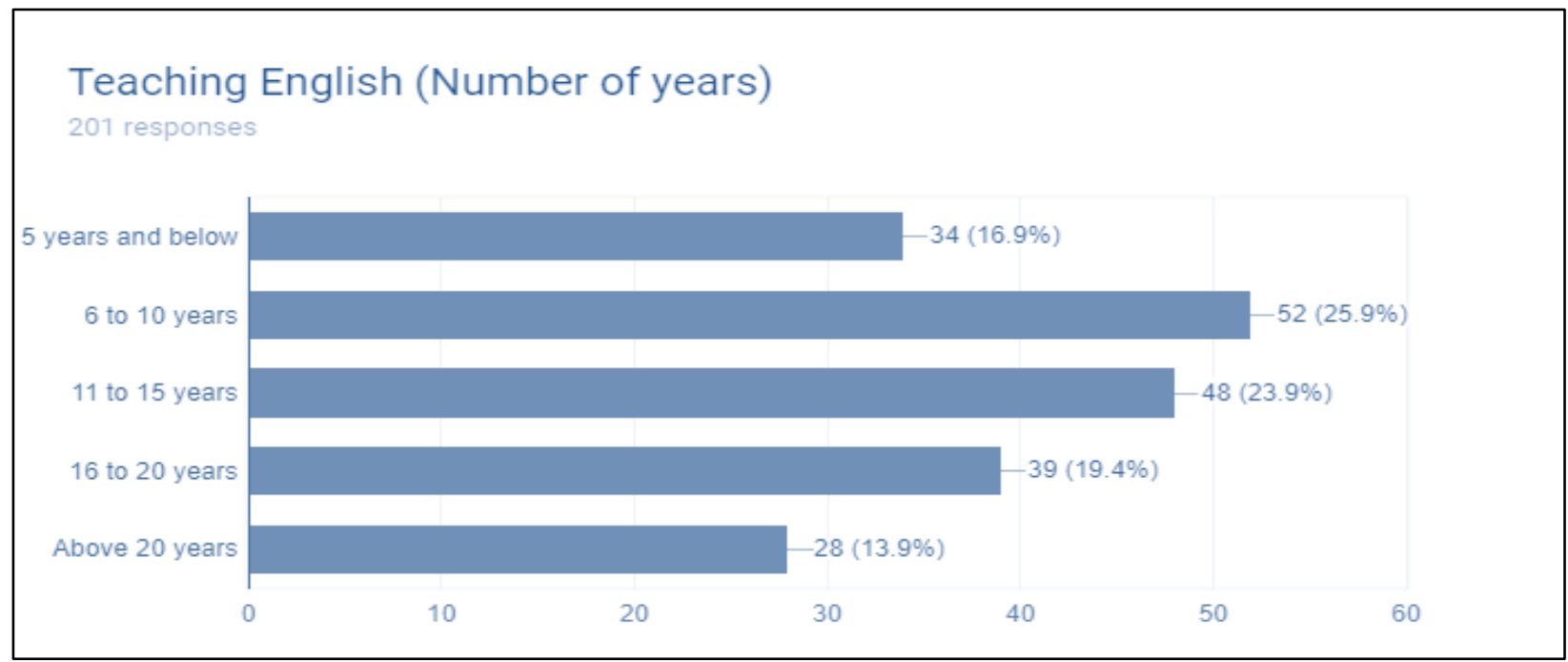

Figure 3. Number of Years teaching the English language

Figure two depicts the teachers' years of experience, whereas Figure three exhibits the teachers' years of teaching the English language. From the chart above, 28 of the participants had 20 years and more experience teaching the English language, 39 had 16 to 20 years. Precisely, 48 of them had taught the English language for 11 to 15 years, while 52 of the participants had six to 10 years of experience in teaching the language. About 34 teachers were new to teaching the English language as they had five years or less experience. The participants in this course were made up of both junior and senior teachers from eight districts nationwide. 
Arab World English Journal (AWEJ) Volume 12. Number 3. September 2021

Boosted with Online Learning to Improve English Language

Dewie,Norman \& Yunus

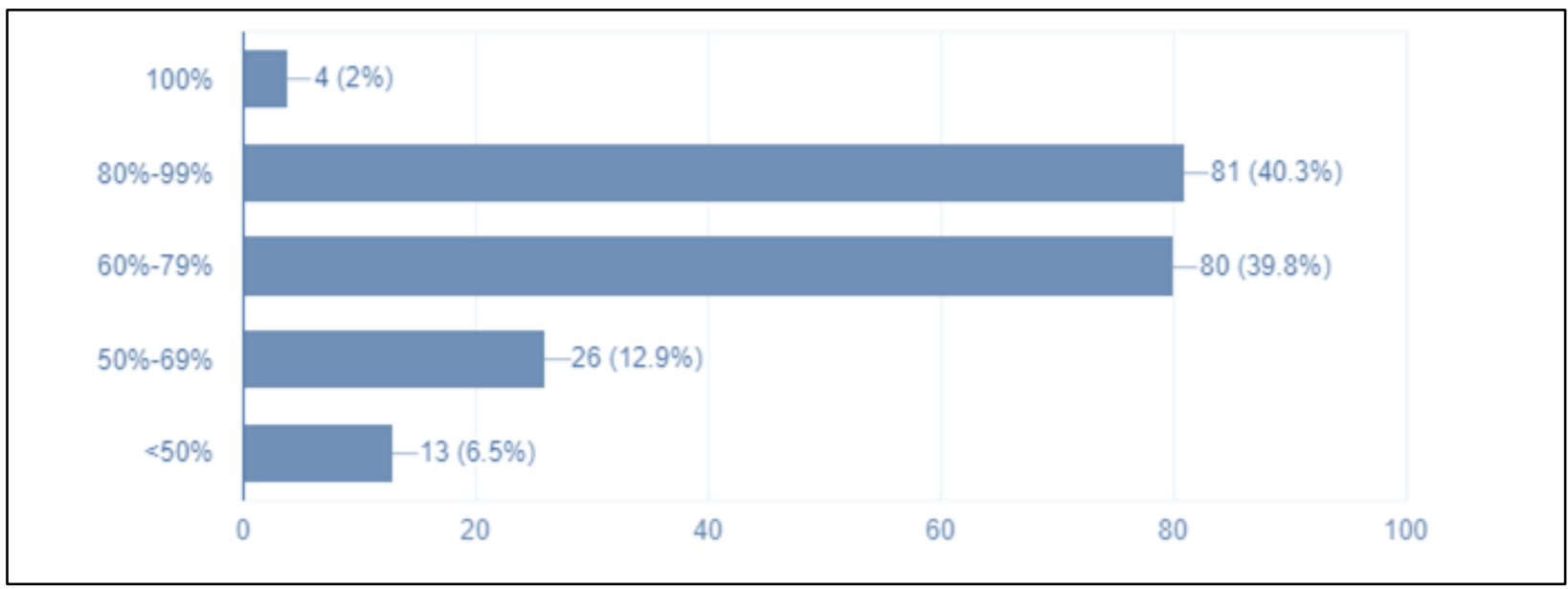

Figure 4. Using the English language as a medium of instruction when teaching the English language in the classroom

According to the data in Figure four, only four teachers from 201 participants use the English language entirely in the classroom. About 80 teachers use from $60 \%$ to $79 \%$ of the English language in the classroom, while 26 teachers use from $50 \%$ to $69 \%$ of the English language in the classroom. Finally, about 13 of them use less than $50 \%$ of the English language in the classroom.

The Malaysian Education Blueprint (MEB) 2013-2025 identifies that education is only transformative when teachers and students synthesize information across subjects and experiences. If teachers are proficient in their instructional language, they can also critically weigh diverse views and combine varied questions across many platforms. Teachers' proficiency in the instructional language, English, may promote critical thinking spaces for both teachers and students by increasing their ability to evaluate, envision, critically synthesize, generate expression, become self-aware, and have intention. According to Garrison (2009), online learning is an opportunity to develop such possibilities.

\section{Findings}

Hence, the teachers' responses through the evaluation form were positive. Generally, the online course was helpful to the English language teachers, as it met their needs and supported them in meeting the course objectives. They had also gained confidence in using the language both inside and outside their teaching arena, and most importantly, they felt they had upskilled themselves. According to the list below, $94 \%$ of the teachers feel positively towards the online course and agree that the course is suitable for its diverse as well as structured organization. 
Arab World English Journal (AWEJ) Volume 12. Number 3. September 2021

Boosted with Online Learning to Improve English Language

Dewie,Norman \& Yunus

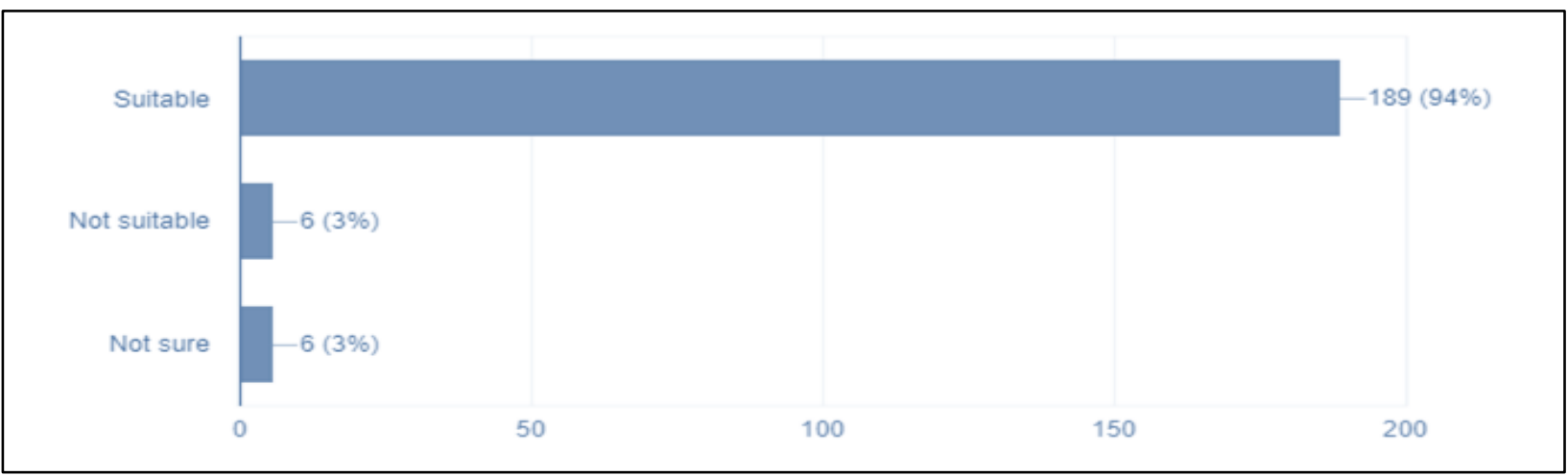

Figure 5. Suitability of the course

The figure below indicates that the course had been beneficial in improving all the language components. The graph demonstrates that most teachers have improved significantly in the vocabulary and speaking components. A large majority of the teachers also felt that they had improved their 'Listening, Reading and Writing' skills throughout the course. However, many teachers felt that the online course did not upskill them in the pronunciation and grammar parts of the English language.

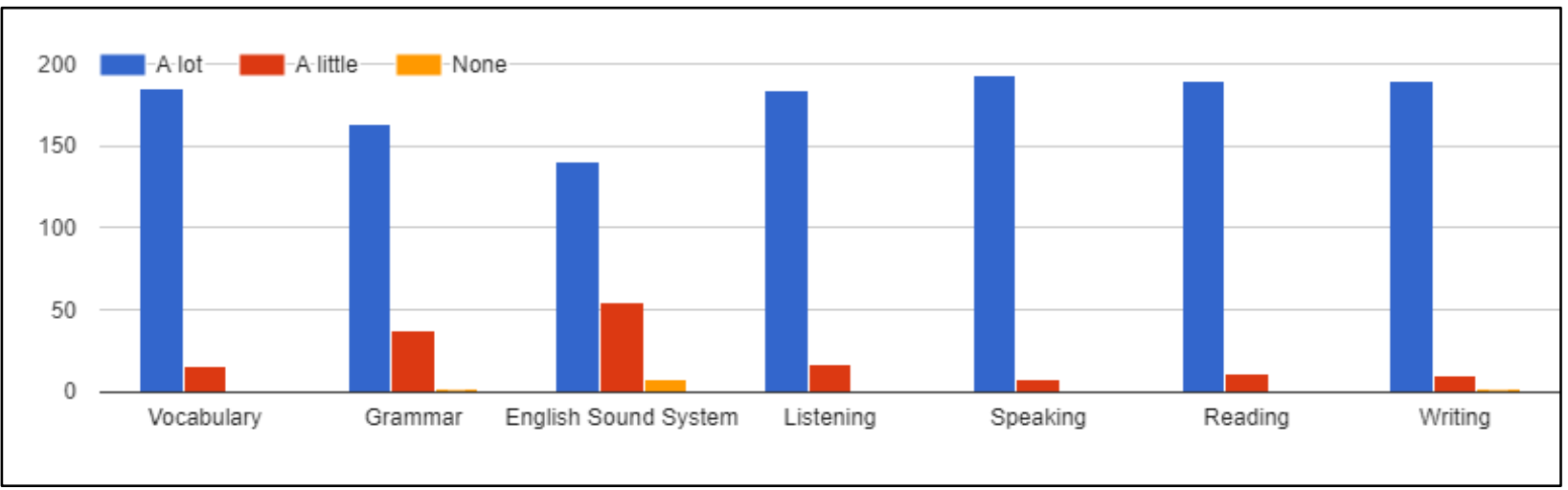

Figure 6. The improvement according to language components

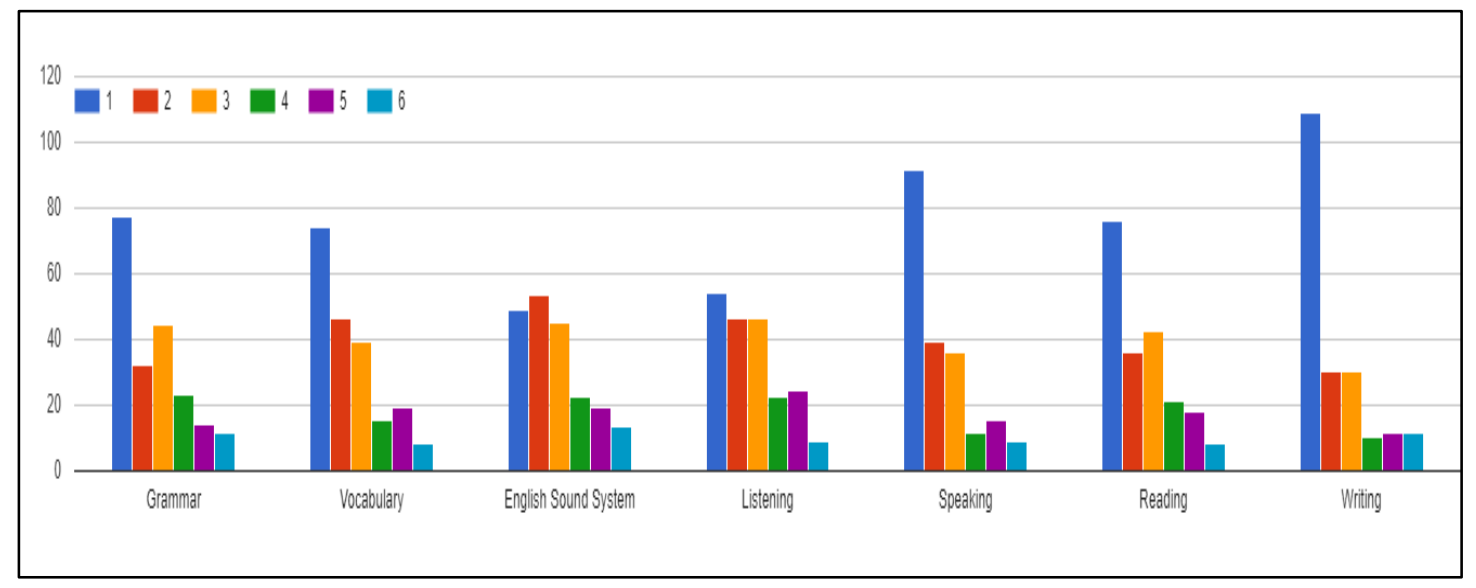

Figure 7. Areas of English do you need to work on most 
Figure seven demonstrates the areas the teachers need help with. It is evident that teachers need the most support with their writing and then speaking. They also need help with grammar, vocabulary and, reading skills. They are not as concerned with sound systems and listening skills.

Figure eight shows that the course has greatly motivated the teachers to use English extensively inside and outside the classrooms. The course had also inspired them to continue upskilling themselves in English language proficiency. Most teachers stated that they were more motivated to learn and use the English language after attending the online class. A tiny minority of teachers, however, indicated that the online course did not significantly influence their motivation to use English with their students or with their colleagues during teaching or conversations.

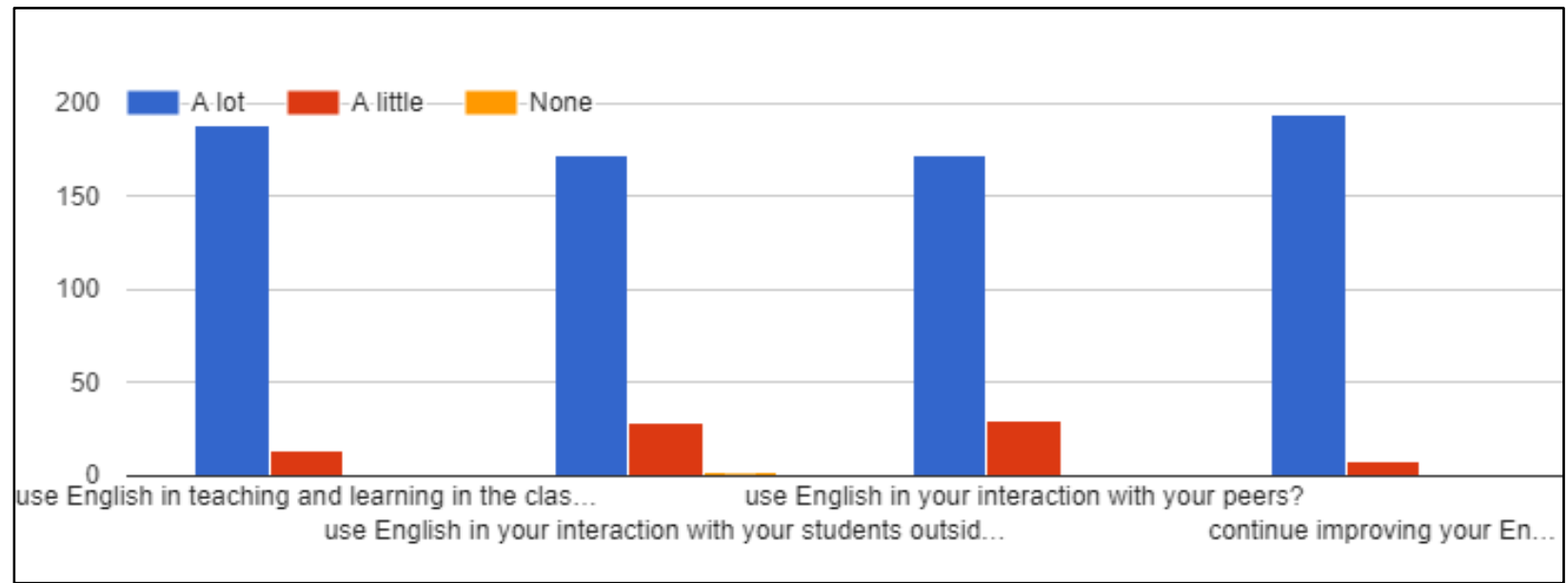

Figure 8. How much has the course motivated the use of English

An overwhelming $97 \%$ of the 201 teachers responded favorably that they would recommend this course to other teachers compared to only six who expressed their unwillingness, as shown in Figure nine.

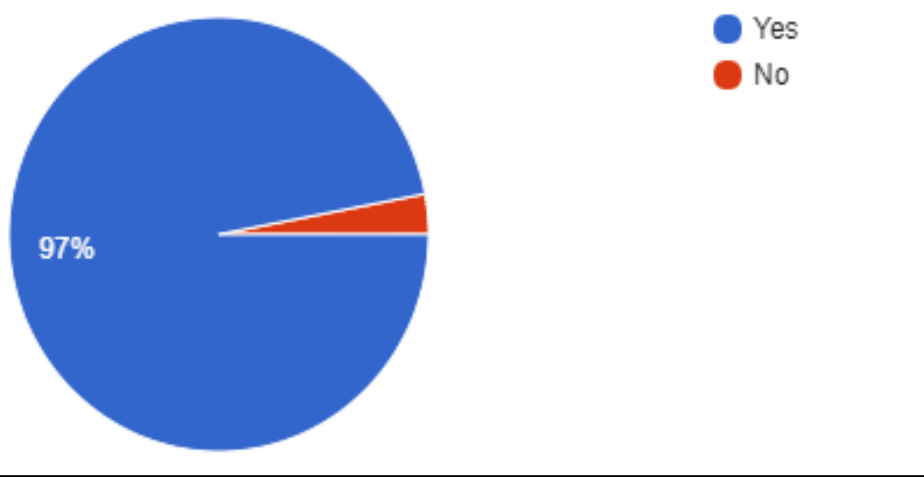

Figure 9. Recommend to others

Figure 10 indicates that the content in the online learning had supported the teachers in improving their reading and writing skills. According to 80 instructors, their listening and speaking abilities have vastly enhanced. As this online module's material is centered on MUET, 
the teachers believe that Grammar, Vocabulary, and Sound Systems are under-emphasized. Thus, the teachers felt that they did not get as much assistance in these parts of the language.

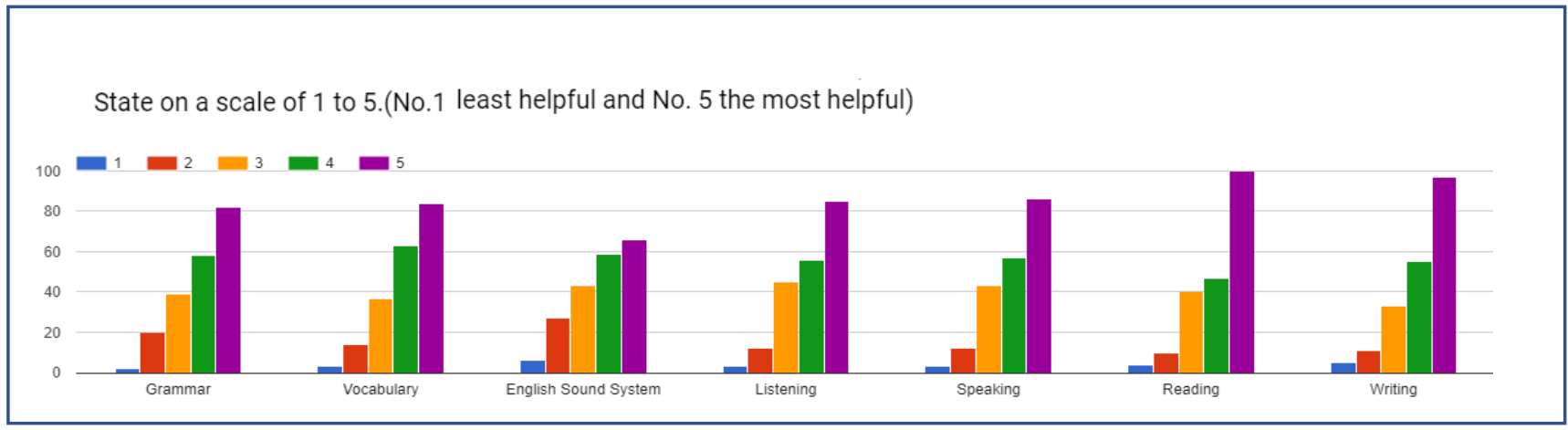

Figure 10. Online content to improve proficiency

About $77.1 \%$ (157 teachers) of the participants stated that the online module was user-friendly. They found navigating via the Canvas LMS platform to be fluid and uncomplicated since the online tasks appealed to both tech-savvy teachers and those who were less inclined to use technology in their day-to-day teaching lives. The online module was specially designed for every teacher to learn at their own pace and location.

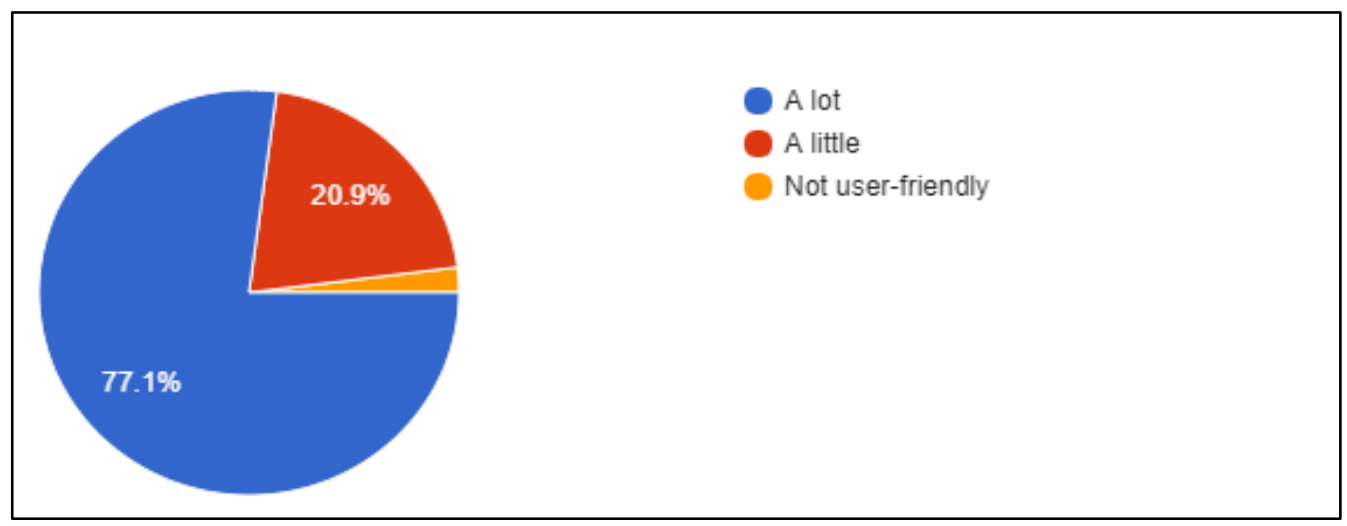

Figure 11. User friendly of the module

\section{Discussion}

Basaza and Milman (2010) indicated that online learning provides opportunities to learners notwithstanding age, gender, socio-economic background, employment status; learners from developed or third world countries, are well portrayed in Figure five. The course participants were homogeneous only in their profession; however, they were of different gender, age group, varied years of teaching experience, diverse cultural and socio-economic backgrounds, and employment statuses as they were from different pay scales. Yet, they resonated with Basaza and Milman's opinion when they stated that the online course had enhanced their proficiency level. Hence, online learning has shifted the paradigm that one needs a specific environment for language learning to language or any other subjects can be learned 
anywhere, any time, and by anyone. This is in tandem with the wave of technological innovations which has engulfed the world today.

In Figure six, the participants, aka teachers, indicated that they had improved in the four skills, namely Listening, Speaking, Reading and, Writing, after attending the course. However, $11 \%$ of them did not concur with the rest as they thought that exam practices provided in the course were insufficient. They wanted strategies to answer the exams which these teachers would be sitting for after the course. In Saka's (2015) research, replies such as these are quite typical, as the systematic analysis of the responses implies that the course's learning outcomes and objectives have been achieved. The study also shows the learner types and their process of language learning. Figure eight, however is a saving grace as it saliently portrays that $90 \%$ of the course participants had been motivated by the course. They were not exam conscious because they felt that they personally had gained. They voluntarily would want to continue with their enhancement.

Finally, 195 teachers (course participants) showed their intent to recommend the course to other teachers in their responses in the evaluation form. It has indicated that the course had benefitted them in the upskilling of their proficiency level, as seen in Figure nine. Most of them found the LMS was user-friendly with tasks and activities designed especially for teachers to comprehend and attempt without many difficulties. Evidently, the course has achieved its' objectives of this study and accomplished with a success story. Thus, regardless of whether or not the learners are tech-savvy, such design is critical for online courses since if courses are made difficult to access and complicated, they will undoubtedly be rejected by learners.

\section{Succinct Views}

The overall experience that the participants had during the online course was that they had thoroughly enjoyed and immersed themselves in it. The evidence is undeniable in the figures displayed in the earlier part of this discussion. Undoubtedly, the participants had to a great extent, achieved the goals of PLCs in that they had with satisfaction indicated that their proficiency in the English language had been enhanced. In addition, they had collaborated as a group and engaged in close communication during their online course, which has created a sense of community among themselves. Teachers who had shown a lack of confidence in English now feel more comfortable using the language they are used to since their content and pedagogical expertise have been enhanced by the course. Furthermore, the objectives to provide an exciting and innovative experience to learners via activities and tasks on online platforms such as Canvas in this course mirrored the experiential learning strategies. According to Budhai and Skipwith (2017), experiential learning strategies are suitable for learners of the $21^{\text {st }}$ century. Throughout the evaluation, teachers showed satisfaction, motivation, and a sense of belonging to the community they had created during the course. However, several complaints from some teachers stated that they were overshadowed in the course. The complaints by the minority group were merely they had not enough practice exercises to prepare them for the MUET exam, which they would sit for after the course. This is a natural reaction as the course participants were expected to get their minimum CEFR C1 qualification after the course.

Such complaints should not be pushed under the carpet as they should be addressed immediately, so that the online course becomes a sought-after course in the teaching fraternity. 
In the Ministry of Education, no teacher should be left behind; that, is the principle the Ministry follows. Thus, more research and studies should be conducted to gain insights on how teaching and learning can effectively take place through online learning. Such study and analyses can also contribute to finding out the learners' attitudes and learning styles which can assist the designers of online modules in creating a meaningful learning environment for teachers.

In nailing, the main aim of the study has been prolifically notable. The findings of this study revealed that online learning had enhanced the proficiency level of teachers in preparing them to obtain the minimum $\mathrm{C} 1$, which is per the requirement of the policy stated in the MEB. The teachers' positive responses to the online module cum course proved that the goal of PLC had been achieved. It is a clear indication that there is no necessity to organize face-to-face learning sessions or courses for teachers anymore. The teaching fraternity is moving towards a self-paced learning mode via online learning courses and programs, giving a flexible option to participants to have the luxury of attending classes at a specific time or location. These teachers were surmounted with responsibilities and duties like all the others, yet they completed the course, justifying the opinion that online courses can succeed among the teaching fraternity. As a result, the teachers' abilities and attitudes are key determinants in ensuring the accomplishment and success of the online course. In the current situation, educators and students are increasingly turning to online learning. The learners and educators chose online classes because there are no restrictions on time and location, and information can be obtained from anywhere and at any time. In addition, it provides the opportunity for lifelong learning.

\section{Conclusion}

Therefore, the recapped conclusion is that this online course has offered a path ahead for teachers to become more dynamic and proficient in their language learning and teaching. It is in line with the aim of MOE to upskill as many teachers as they can by 2025, the last wave of the Malaysian Education Blueprint. As the Ministry has spent a great deal of money on a face-toface course, the expense of bringing and providing meals with accommodation is lowered to nothing because course participants may attend the course from wherever they are. Teachers' professional development costs can be minimized by offering such courses. The increased demand for the course will place our policymakers and relevant authorities in a better stance to provide easily accessible platforms for upskilling and the professional development of teachers. The reduced cost will also enable more teachers to achieve the target of MEB, which is, all teachers are at $\mathrm{C} 1$ by the year 2025 .

Lastly, though positive findings are abundant in this study, there were limitations, such as most of the teachers were from primary schools, and all were from Malaysia. Then, though teachers were from different districts, the socio-cultural differences were not that apparent. There wasn't adequate time allotted to investigate the teachers' learning methods and retention rates. If these factors had been given more attention, the findings may have been expanded into further discoveries. Second, this study did not focus on more in-depth analysis such as multivariate analysis (e.g., partial least squares-structural equation modelling). In the future, this mode of analysis is encouraged to analyze variables related to teacher proficiency in online learning. Finally, over the course of 90 days, an analysis of all four major components of teacher's progress was completed. As a result, too much time was spent on all of the skills over the course of three months, resulting in no comprehensive study for any one skill in particular. It 
is strongly recommended that one skill be prioritized in order to gain deeper insights and better findings, making the study more valuable to the stakeholders (organizers, teachers, students, and parents). It would be future directions for others then.

\begin{abstract}
About the authors
Szarmilaa Dewie Krishnan is a teacher trainer at the English Language Teaching Centre (ELTC), Ministry of Education Malaysia. She holds a M.Ed (TESL) from the University of Malaya and currently pursuing her PhD in Instructional Technology of Education at Universiti Kebangsaan Malaysia (UKM). She is also the Director of Training Bureau of Malaysian English Language Association (MELTA). ORCid ID: https://orcid.org/0000-0002-4005-2951
\end{abstract}

Assoc. Prof. Ts Dr Muhammad Helmi Norman is currently the Deputy Director of Instructional Technologies of the Center for Teaching and Curriculum Development, Universiti Kebangsaan Malaysia (UKM) and currently drives the e-learning transformation in the university. He is also an Associate Professor at the Research Center for Teaching and Learning Innovations, Faculty of Education. His research interests are in the field of digital learning and futuristic education. He is an Apple Distinguished Educator and Apple Professional Learning Specialist where he is involved in educational transformations at primary, secondary, and higher education levels in promoting 1:1 pedagogical and learning approaches using the Apple ecosystem and is a certified professional technologist of the Malaysian Board of Technologists. ORCid ID: https://orcid.org/0000-0002-4717-3166

Assoc. Prof. Dr. Melor Md Yunus is an Associate Professor and Deputy Dean of Research and Innovation at the Faculty of Education, Universiti Kebangsaan Malaysia. She is best known for establishing the integration of ICT in teaching and learning English as a Second Language research. She is active in scholarly journal writing and publishing. The recipient of more than 200 innovation awards, she is highly regarded among her peers in her field. ORCid ID: https://orcid.org/0000-0001-7504-7143

\title{
Acknowledgment
}

This research was funded by UNIVERSITI KEBANGSAAN MALAYSIA, grant number GG2021-012 and TAP-K021084.

\section{References}

Andersen, B. L., Na-songkhla, J., Hasse, C., Nordin, N., \& Norman, H. (2018). Perceptions of authority in a massive open online course: An intercultural study. International Review of Education, 64(2), 221-239.

Artino, A. R., \& Jones, K. D. (2012). Exploring the complex relations between achievement emotions and self-regulated learning behaviors in online learning. The Internet and Higher Education, 15(3), 170-175.

Boetthcher, J. \& Conrad, R. (2016). The Online Teaching. San Francisco: Jossey-Bass

Budhai, S.S., \& Skipwith, K.B. (2017). Best Practice in Engaging Online Learners through

Active and Experiential Learning Strategies. New York: Routledge

Cárdenas Ramos, R., \& Chaves Varón, O. (2013). English Teaching in Cali: Teachers'

Proficiency Level Described. Lenguaje, 41(2), 325-352. DOI:

10.25100/lenguaje.v41i2.4971 
Arab World English Journal (AWEJ) Volume 12. Number 3. September 2021

Boosted with Online Learning to Improve English Language

Dewie,Norman \& Yunus

Cavus, N., Uzunboylu, H., \& Ibrahim, D. (2007). Assessing the Success Rate of Students Using a Learning Management System Together with a Collaborative Tool in Web-Based Programming Languages. Journal Of Educational Computing Research, 36(3), 301-321. DOI: $10.2190 / \mathrm{t} 728-\mathrm{g} 676-4 \mathrm{n} 18-6871$

Chua, C.N., Yunus, M. M., \& Suliman, A. (2019). ICT: An Effective Platform to Promote Writing Skills among Chinese Primary School Pupils. Arab World English Journal, 10(4) 223-237. DOI: https://dx.doi.org/10.24093/awej

United States Distance Learning Association. (2011). Distance Learning for Educators, Trainers, and Leaders, 8(1). Retrieved from https://fr.scribd.com/document/361932449/Distancelearning-for-educators-trainers-and-leaders-Vol-8-No-1-2011-2

Dogan, H.et all. (2019). A Web-Based Intervention for Social Media Addiction Disorder Management in Higher Education: Quantitative Survey Study. Journal of Medical Internet Research, 21(10), e14834.

Ferri, F., Grifoni, P., \& Guzzo, T. (2020). Online Learning and Emergency Remote Teaching: Opportunities and Challenges in Emergency Situations. Societies, 10(4), 86. DOI:

$10.3390 /$ soc 10040086

Forsberg, J. (2018). Gamification in Education - Utilization in Teaching of Languages. Bachelor's Degree. Aalto University.

Freeman,D., Katz,A., Gomez, P.B, \& Burns, A. (2015). English-for-Teaching: Rethinking Teacher Proficiency in the Classroom. ELT Journal, 69(2), 129-139.DOI: https://doi.org/10.1093/elt/ccu074

Garrison, R. (2009). Implications of Online Learning for the Conceptual development and Practice of Distance Education. Journal of Distance Education, 23(2), 93-104.

Gatta, M. (2009). Online Learning for Low Skill Adults. America: Rutgers.

Harley, B., Allen, P., Cummins, J., \& Swain, M. (Eds). (1990). The Development of Second Language Proficiency. Cambridge: Cambridge University Press

Hattie, J., Biggs, J., \& Purdie, N. (1996). Effects of learning skills interventions on student learning: A meta-analysis. Review of Educational Research, 66(2), 99-136.

DOI: https://doi.org/10.2307/1170605

Hashim, H., Rafiq, K. R. M., \& Yunus, M. M. (2019). Improving ESL Learners' Grammar with Gamified-Learning. Arab World English Journal (AWEJ) Special Issue on CALL, (5). 41-

50 DOI: https://dx.doi.org/10.24093/awej/call5.4

Howard, J. M., \& Scott, A. (2017). Any Time, Any Place, Flexible Pace: Technology-Enhanced Language Learning in a Teacher Education Programme. Australian Journal of Teacher Education, 42(6). 51-68. Retrieved from $\quad$ http://ro.ecu.edu.au/ajte/vol42/iss6/4

Kaarakainen, M.-T., Kivinen, A., \& Kaarakainen, S.-S. (2017). Differences between the genders in ICT skills for Finnish upper comprehensive school students: Does gender matter? Seminar.net, 13(2). Retrieved from https://journals.oslomet.no/index.php/seminar/article/view/2304

Kepol, N. (2017). Quality Malaysian English Language Teachers: Examining A Policy Strategy. Malaysian Journal Of Learning And Instruction, (Vol. 14, No. 1 June 2017), 187 209. DOI: $10.32890 / \mathrm{mjli2} 2017.14 .1 .8$

Krishnan, P. D., \& Yunus, M. M. (2019). Blended CEFR in Enhancing Vocabulary among Low Proficiency Students. Arab World English Journal (AWEJ) Special Issue on CALL (5). 141153. DOI: https://dx.doi.org/10.24093/awej/call5.11

Le, V, C., \& Renandya, W, A. (2017). Teachers' English Proficiency and Classroom 
Arab World English Journal (AWEJ) Volume 12. Number 3. September 2021

Boosted with Online Learning to Improve English Language

Dewie,Norman \& Yunus

Language Use: A Conversation Analysis Study. RELC Journal, 48(1), 67-81.DOI: https://doi.org/10.1177/0033688217690935

Lee, J., \& Lee, W. (2008). The relationship of e-Learner's self-regulatory efficacy and perception of e-Learning environmental quality. Computers In Human Behavior, 24(1), 32-47. DOI: 10.1016/j.chb.2006.12.001

Major, C.H. (2015). Teaching Online. United States: Johns Hopkins University Press

Maican, M., \& Cocoradă, E. (2021). Online Foreign Language Learning in Higher Education and Its Correlates during the COVID-19 Pandemic. Sustainability, 13(2), 781. DOI: $10.3390 / \mathrm{su} 13020781$

Malmberg, E. (2018). A Study on Gamification and Feedback Use by English Teachers in Swedish Upper Secondary School. Master's Degree. Dalarna University

McGreal, R. (2018). Hearables for online learning. The International Review of Research in Open and Distributed Learning, 19(4), 260-267.

Nguyen, T. (2015). The Effectiveness of Online Learning: Beyond No Significant Difference and Future Horizons. Journal Of Online Learning And Teaching, 11(2), 309-319.

Yunus, M.M, Umiera Hashim, H., \& Hashim, H. (2019). Massive Open Online Courses: En Route to Communication Skills Acquisition. Arab World English Journal, 5(5), 98-109. DOI: 10.24093/awej/call5.8

Ministry of Education Malaysia, 2013. Malaysian Education Blueprint 2013-2025. Putrajaya: Kementerian Pelajaran Malaysia

Ministry of Education Malaysia, 2015. The Roadmap 2015-2025. Putrajaya: Kementerian Pelajaran Malaysia

Morrison, G.R., Ross, S.M., \& Kemp, J.E. (2004). Designing Effective Instruction. United States of America: John Wiley \& Sons

Nordin, N., Norman, H., Embi, M. A., Mansor, A. Z., \& Idris, F. (2016). Factors for Development of Learning Content and Task for MOOCs in an Asian Context. International Education Studies, 9(5), 48-61.

Norman, H., Din, R., \& Nordin, N. (2011). A Preliminary Study of an Authentic Ubiquitous Learning Environment for Higher Education. Proceedings of the 10th WSEAS eActivities, 89-94.

Norman, H., Nordin, N., Din, R., Ally, M., \& Dogan, H. (2015). Exploring the Roles of Social Participation in Mobile Social Media Learning: A Social Network Analysis. The International Review of Research in Open and Distributed Learning, 16(4). 205-224. DOI: 10.19173/irrodl.v16i4.2124

Pintrich, P. R., \& Johnson, G. R. (1990). Assessing and improving students' learning strategies. New Directions for Teaching and Learning, (42), 83-92.DOI: 10.1002/t1.37219904209

Pramela, K., \& Supyan, H. (2015). Online Forum and Language Learning Pedagogical Consideration. Serdang: Universiti Putra Malaysia Press

Rahmat, R. M. et al. (2012). Measuring learners' perceived satisfaction towards e-learning materials and environment. Retrieved from https://www.researchgate.net/publication/277721232_Measuring_Learners'_ Perceived_Satisfaction_Towards_e-Learning_Material_and_Environment

Richards, H., Conway, C., Roskvist, A., \& Harvey, S. (2013). Foreign language teachers' language proficiency and their language teaching practice. The Language Learning Journal, 41(2), 231-246. DOI: 10.1080/09571736.2012.707676

Saka, F. Ö. (2015). What Exam Papers Make Us Think? Procedia - Social and Behavioral 
Sciences, 199, 298-304. doi: 10.1016/j.sbspro.2015.07.549

Shea-Schultz, H. and Fogarty, J. (2002). Online Learning Today. San Francisco: Berrett-Koehler

Shih, C. C., \& Gamon, J. A. (2002). Relationships among learning strategies, patterns, styles, and achievement in web-based courses. Journal of Agricultural Education, 43(4), 1- 11. DOI:10.5032/JAE.2002.04001

Singh, K. K. A. H., \& Yunus, M. M. (2021). Using E-Learning in English Language Teaching: A Systematic Review. International Journal of Academic Research in Progressive Education and Development, 10(1), 51-62.DOI: 10.6007/IJARPED/v10-i1/8338

Solak, E., \& Cakir, R. (2015). Language learning strategies of language e-learners in Turkey. ELearning and Digital Media, 12(1), 107- 120.

Stavredes, T. (2011). Effective Online Teaching. San Francisco: Jossey-Bass

Yasmin K. Z. N., Norman, H., Yunus, M.M., Hashim, H., \& Nordin, N. (2018). Learning Analytics View on Dispersion of Learning in MOOCs. International Journal of Engineering \& Technology, 7(4.21), 7-10. DOI: http://dx.doi.org/10.14419/ijet.v7i4.21.21606

Yunus, M. M. (2018). Innovation in Education and Language Learning In 21st Century. Journal of Sustainable Development Education and Research, 2(1), 33. DOI:10.17509/Jsder.V2i1.12355

Yunus, M.M, Hashim, H., Embi, M., \& Lubis, M. (2010). The utilization of ICT in the teaching and learning of English: 'Tell Me More'. Procedia - Social and Behavioral Sciences, 9, 685691. DOI: 10.1016/j.sbspro.2010.12.218

Zimmerman, B. (2000). Attaining self-regulation: A social cognitive perspective. In M. Bockacrts, P. R. Pintrich, \& M. Zeidner, (Eds), Handbook of self-regulation, (pp. 1339).Academic Press. 